\title{
Lead-210 and plutonium fallout in Taiwan as recorded at a subalpine lake
}

\author{
Chih-An Huh, ${ }^{*}$ Keng-Sheng Chu, $\uparrow$ Ching-Ling Wei $\dagger$ and Ping-Mei Liew $\ddagger$ \\ *Institute of Earth Sciences, Academia Sinica, Taipei, Taiwan, ROC; †Institute of Oceanography, \\ National Taiwan University, Taipei, Taiwan, ROC; $¥$ Department of Geology, National Taiwan \\ University, Taipei, Taiwan, ROC
}

(Received 23 January 1996; accepted for publication 13 August 1996)

\begin{abstract}
A sediment core collected from the Sun Moon Lake in middle Taiwan was investigated for ${ }^{210} \mathrm{~Pb}$ and ${ }^{239,240} \mathrm{Pu}$. Based on the decrease of excess ${ }^{210} \mathrm{~Pb}$ with depth, the mean sedimentation rate in the lake during the past half century is about $0.9 \mathrm{~cm} \mathrm{yr}^{-1}$, which is unequivocally supported by the appearance of the 1963 plutonium fallout maximum at $26-28 \mathrm{~cm}$. The short-term sedimentation rate is one order of magnitude greater than ${ }^{14} \mathrm{C}$-based long-term sedimentation rates in the lake reported previously. This may be attributed to the deterioration of soil conservation associated with the construction of a dam five decades ago.

Total downcore inventories of excess ${ }^{210} \mathrm{~Pb}$ and ${ }^{239,240} \mathrm{Pu}$ are $54.5 \mathrm{dpm} \mathrm{cm}^{-2}$ and $0.21 \mathrm{dpm} \mathrm{cm}^{-2}$, respectively. This ${ }^{210} \mathrm{~Pb}$ inventory requircs a flux of $1.7 \mathrm{dpm} \mathrm{cm}^{-2} \mathrm{yr}^{-1}$ at stcady state, which is similar to ${ }^{210} \mathrm{~Pb}$ fluxes observed at other sites in the western Pacific rim. The inventory of ${ }^{239,240} \mathrm{Pu}$ is in excellent agreement with documented cumulative ${ }^{239.240} \mathrm{Pu}$ from global fallout $\left(0.96 \pm 0.07 \mathrm{mCi} \mathrm{km}^{-2}\right)$ at the $20-30^{\circ} \mathrm{N}$ latitudinal band. Our data suggest that the Sun Moon Lake is an ideal setting for monitoring atmospheric fallout and environmental changes in this region. (C) 1997 Elsevier Science Ltd. All rights reserved
\end{abstract}

\section{Introduction}

Lead-210, a daughter product in the ${ }^{238} \mathrm{U}$ decay series, is produced by the decay of ${ }^{222} \mathrm{Rn}$ which, as an inert gas, emanates from soils into the atmosphere. Once produced, ${ }^{210} \mathrm{~Pb}$ becomes associated with aerosols and is removed from the atmosphere by wet or dry precipitation. Due to the constant production, its particlereactive nature and suitable half-life (of $22.26 \mathrm{yr}$ ), ${ }^{210} \mathrm{~Pb}$ has long been established as a chronometer for measuring accumulation rates of glaciers (Goldberg 1963), lacustrine sediments (Krishnaswami et al. 1971) and near-shore marine sediments (Koide et al. 1972) on time scales of 10-100 yr. The first objective of this study is to determine the ${ }^{210} \mathrm{~Pb}$-based sedimentation rate of a Sun Moon Lake sediment core and derive the flux of ${ }^{210} \mathrm{~Pb}$ in the sediment. In recent years, the local scientific community has increased interests in using lakes as test grounds to address issues about environmental changes. As the largest lake in Taiwan, the Sun Moon Lake has attracted much attention. To support such research, it is critical to establish sediment chronology for the lake.

Plutonium is an anthropogenic element whose major source to the environment has been the deposition on to the earth of over $400 \mathrm{kCi}$ of ${ }^{239.240} \mathrm{Pu}$ from atmospheric weapons testing during the past half century. Although the flux and inventory of fallout $\mathrm{Pu}$ have been measured worldwide (Hardy et al. 1973; Sholkovitz 1983 and references therein), such information is extremely rare in Southeast Asia and nonexistent in Taiwan. With the ${ }^{210} \mathrm{~Pb}$ chronology established, the second objective of this study is to reconstruct the time series of Pu fallout in the region. Furthermore, from the distribution of ${ }^{239,240} \mathrm{Pu}$ in sediments of the lake, cumulative inventory of $\mathrm{Pu}$ can be calculated. As such, besides filling the geographic data gap, this work will establish important database for future environmental research in Taiwan.

The Sun Moon Lake (also voice translated from Chinese as Jih-Yüeh T'an) is located near the geographic center of the island (Fig. 1). Physiology of the lake experienced drastic changes in the 1920s and 1930s due to human activities. Prior to 1919, the lake surface was $727 \mathrm{~m}$ above sea level, with an original surface area of $5.4 \mathrm{~km}^{2}$ and mean water depth of $4.6 \mathrm{~m}$. Following the construction of a dam which was completed in 1939, the water table could rise by as much as $23 \mathrm{~m}$ (to reach $750 \mathrm{~m}$ above sea level) and the surface area of the reservoir could expand to $8.8 \mathrm{~km}^{2}$. Located in the Central Mountain Range, the Sun Moon Lake virtually has no catchment basin. Therefore, the lake lends itself as an ideally suited natural setting for monitoring atmospheric fallout of ${ }^{210} \mathrm{~Pb}$ and ${ }^{239,240} \mathrm{Pu}$, as well as other signals of environmental implications in the Taiwan region and its vicinity.

\section{Sampling and analytical methods}

The core used for this study was collected on 11 January 1995 in a water depth of $26.8 \mathrm{~m}$ at the southern part of the Sun Moon Lake (Fig. 1). A piston corer was used. Upon its collection, the core was kept upright and transported to the laboratory for subsampling. A plunger was used to push the mud up the core barrel for the sectioning of successive intervals. The sampling intervals were every $1 \mathrm{~cm}$ in the top $20 \mathrm{~cm}$, increasing to 
$2 \mathrm{~cm}$ between 20 and $30 \mathrm{~cm}$ and $3 \mathrm{~cm}$ thereafter. About $0.5 \mathrm{~cm}$ was trimmed from the outer rim of each slab to avoid mixing of downtrained material along the inner walls of the core barrel. The samples were dried in an oven at $60^{\circ} \mathrm{C}$ to constant weights. Water content (wt $\%$ $\mathrm{H}_{2} \mathrm{O}$ ) was calculated from the weight loss, and porosity ( $\phi)$ was calculated by: $\phi=$ wet density $\times \% \mathrm{H}_{2} \mathrm{O}$ / $100 \times \mathrm{cm}^{3} \mathrm{~g}^{-1}$.

To facilitate radiochemical analysis the samples were ground into a fine powder using a pestle and mortar. About $5 \mathrm{~g}$ dry sediment powder was weighed out, spiked with ${ }^{209} \mathrm{Po}$ and ${ }^{242} \mathrm{Pu}$, and digested sequentially with a mixture of $\mathrm{HF}, \mathrm{HCl}$ and $\mathrm{H}_{3} \mathrm{BO}_{3}$ (at 4:4:1 volume ratio) to dissolve inorganic material (primarily aluminum silicates). After heating the sample solution to dryness, the residue was further digested with a mixture of $\mathrm{HNO}_{3}$ and $\mathrm{HClO}_{4}$ (at 3:1 volume ratio) to decompose organic matter. Isotopic equilibration is attained by quantitative dissolution of the samples. Radiochemical separation and purification of $\mathrm{Po}$ - and $\mathrm{Pu}$-isotopes were conducted using procedures similar to those described elsewhere (Bacon et al. 1985). Note that ${ }^{210} \mathrm{~Pb}$ is measured via its daughter ${ }^{210} \mathrm{Po}$ (half-life $=138$ days) by alpha spectrometry. Because the half-life of ${ }^{210} \mathrm{Po}$ is much shorter than that of ${ }^{210} \mathrm{~Pb}$, this parent-daughter pair is in radioactive equilibrium in the sediment samples. The purified $\mathrm{Po}$ and $\mathrm{Pu}$ sources were plated on to silver and stainless steel planchets, respectively, and counted using silicon surface-barrier detectors interfaced to a multichannel analyzer.

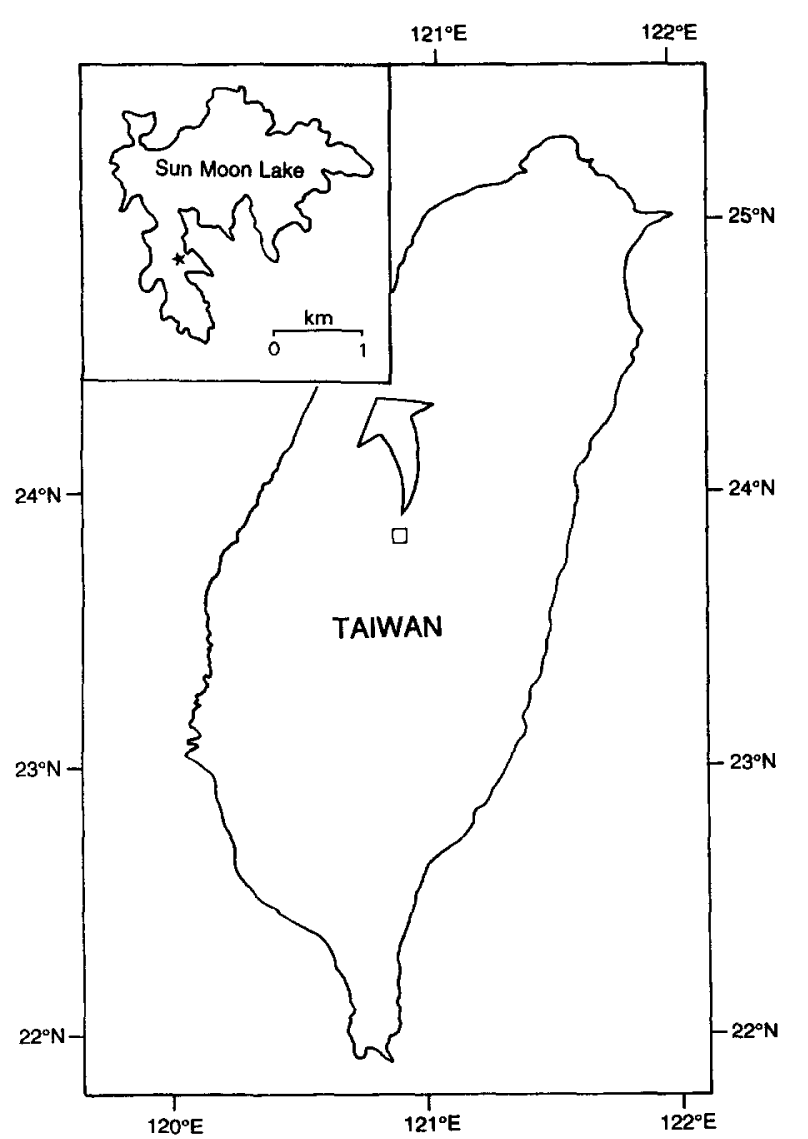

Fig. 1. Location of the Sun Moon Lake and the coring site (indicated by star).
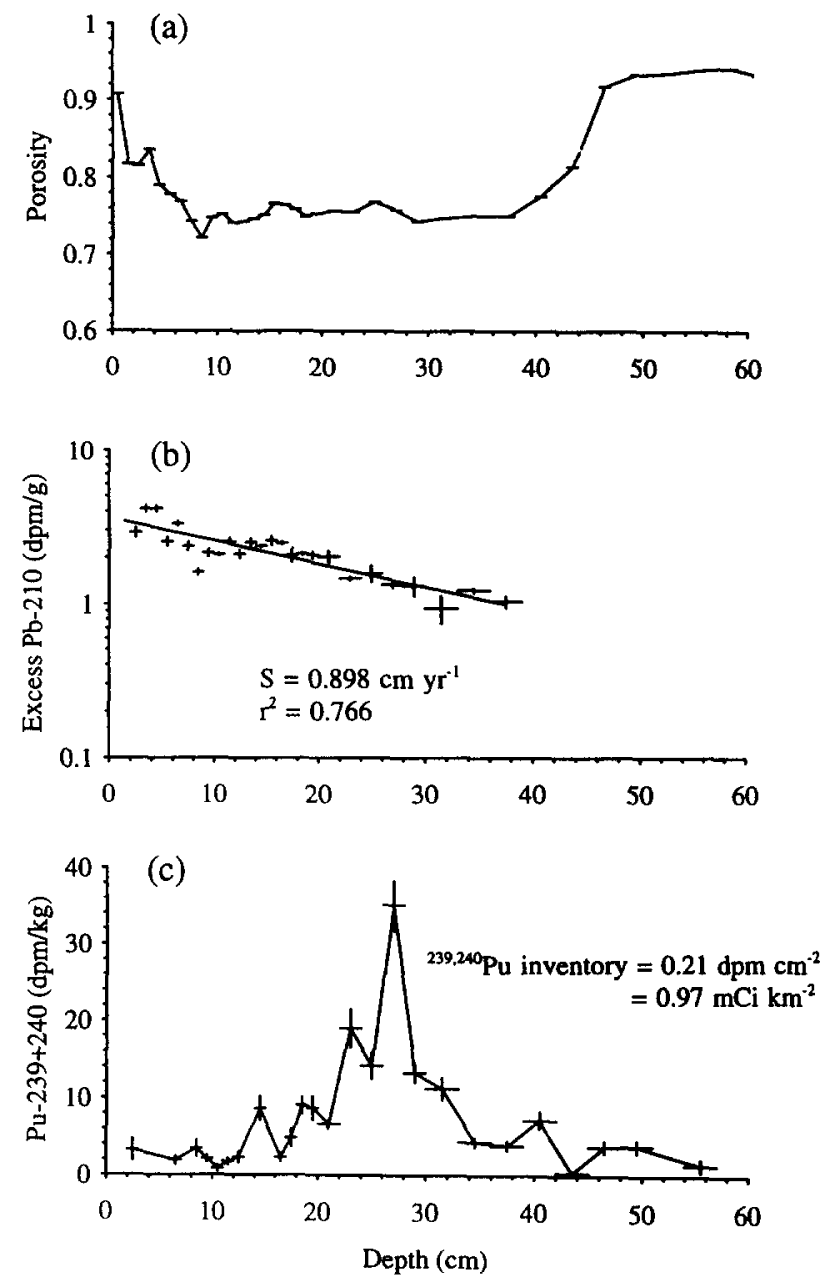

Fig. 2. Downcore profiles of (a) porosity, (b) excess ${ }^{210} \mathrm{~PB}$ and (c) ${ }^{239,240} \mathrm{Pu}$

\section{Results and discussion}

Downcore distributions of water content, porosity, excess ${ }^{210} \mathrm{~Pb}$ and ${ }^{239,240} \mathrm{Pu}$ are listed in Table 1 and shown in Fig. 2. Porosity, calculated by assuming a sediment dry density of $2.6 \mathrm{~g} \mathrm{~cm}^{-3}$, decreases with depth from $\sim 0.9$ to $\sim 0.75$ in the top $10 \mathrm{~cm}$ and remains fairly constant from 10 to $40 \mathrm{~cm}$. Below $40 \mathrm{~cm}$, porosity increases sharply to values greater than 0.9 . Profile of excess ${ }^{210} \mathrm{~Pb}$ (Fig. 2b) exhibits the expected exponential decrease in the top $40 \mathrm{~cm}$, but followed by an abnormal increase just below $40 \mathrm{~cm}$ (see Table 1). These anomalous trends can be correlated to a distinct boundary near $40 \mathrm{~cm}$ below which bulk of the material was made up of plant debris. The construction of the dam is most likely responsible for these changes. The rise of the reservoir water level and its fluctuation associated with hydropower generation and annual pattern of precipitation could enhance erosion of soils from the original lake banks and exploited terrain above.

Under the assumption of a constant ${ }^{210} \mathrm{~Pb}$ flux and a constant sedimentation rate, the concentration of excess ${ }^{210} \mathrm{~Pb}$ can be described by:

$$
\mathrm{C}=\mathrm{C}_{\mathrm{o}} \exp [(-\lambda / \mathrm{S}) \mathrm{Z}]
$$

or

$$
\ln C=\ln C_{o}-(\lambda / S) Z
$$


where $Z(\mathrm{~cm})$ is depth in core, $\mathrm{C}\left(\mathrm{dpm} \mathrm{g}^{-1}\right)$ is the activity of excess ${ }^{210} \mathrm{~Pb}$ at $\mathrm{Z}, \mathrm{C}_{\mathrm{o}}$ is $\mathrm{C}$ at $\mathrm{Z}=0 ; \lambda\left(=0.0311 \mathrm{yr}^{-1}\right)$ is the decay constant of ${ }^{210} \mathrm{~Pb}$, and $\mathrm{S}\left(\mathrm{cm} \mathrm{yr}^{-1}\right)$ is the sedimentation rate. If the above assumption is met, the distribution of excess ${ }^{210} \mathrm{~Pb}$ is expected to follow a straight line on a semi-logarithmic plot. From the intercept $\left(\ln C_{0}\right)$ and the slope $\left(-\lambda \mathrm{S}^{-1}\right)$ of the regression line, $\mathrm{C}_{0}$ and $\mathrm{S}$ can be obtained. Based on excess ${ }^{210} \mathrm{~Pb}$ distribution in the top $40 \mathrm{~cm}, \mathrm{~S}=0.898 \mathrm{~cm} \mathrm{yr}^{-1}$ and $\mathrm{C}_{\mathrm{o}}=3.62 \mathrm{dpm} \mathrm{g}^{\prime}\left(\mathrm{r}^{2}=0.766, \mathrm{n}=28\right)$. If we take sediment porosity into account and calculate $S$ and $C_{0}$ with the compaction corrected depths $\left(\mathrm{g} \mathrm{cm}^{-2}\right)$, $\mathrm{S}=0.458 \mathrm{~g} \mathrm{~cm}^{-2} \quad \mathrm{yr}^{-1}$ and $\mathrm{C}_{\mathrm{o}}=3.70 \mathrm{dpm} \quad \mathrm{g}^{-1}$ $\left(\mathrm{r}^{2}=0.712, \mathrm{n}=28\right)$. It is found that chronologies derived from these two rates $\left(0.898 \mathrm{~cm} \mathrm{yr}^{-1}\right.$ and $0.458 \mathrm{~g}$ $\mathrm{cm}^{-2} \mathrm{yr}^{-1}$ ) are essentially the same. The second set of parameters can be used more directly for calculating fluxes and inventories (see later).

The first attempt to date Sun Moon Lake sediments was made by Stuiver $(1967,1970)$ using ${ }^{14} \mathrm{C}$. Stuiver's ${ }^{14} \mathrm{C}$-based sedimentation rates were one to two orders of magnitude lower than our ${ }^{210} \mathrm{~Pb}$-based rate. It should be noted that the ${ }^{14} \mathrm{C}$ ages Stuiver obtained for the "surface" sediments are 1-2 thousand years old, and he acknowledged that due to incomplete recovery the top

Table 1. Water content, wet density, porosity, and activities of excess ${ }^{210} \mathrm{~Pb}$ and ${ }^{239,240} \mathrm{Pu}$ in Sun Moon Lake sediments

\begin{tabular}{|c|c|c|c|c|c|}
\hline $\begin{array}{l}\text { Depth } \\
\text { (cm) }\end{array}$ & $\% \mathrm{H}_{2} \mathrm{O}$ & $\begin{array}{c}\text { Wet } \\
\text { density } \\
\left(\mathrm{g} / \mathrm{cm}^{3}\right)\end{array}$ & Porosity & $\begin{array}{c}{ }^{210} \mathrm{~Pb}_{\mathrm{ex}} \\
(\mathrm{dpm} / \mathrm{g})\end{array}$ & $\begin{array}{c}{ }^{219,240} \mathrm{Pu} \\
(\mathrm{dpm} / \mathrm{kg})\end{array}$ \\
\hline $0-1$ & 79.09 & 1.147 & 0.908 & - & - \\
\hline $1-2$ & 63.19 & 1.293 & 0.817 & $2.03 \pm 0.25$ & - \\
\hline $2-3$ & 62.86 & 1.296 & 0.815 & $2.90 \pm 0.20$ & $3.24 \pm 0.45$ \\
\hline $3-4$ & 66.00 & 1.264 & 0.835 & $4.12 \pm 0.19$ & - \\
\hline $4-5$ & 59.12 & 1.336 & 0.790 & $4.15 \pm 0.19$ & - \\
\hline $5-6$ & 57.48 & 1.354 & 0.779 & $2.53 \pm 0.16$ & - \\
\hline $6-7$ & 56.11 & 1.370 & 0.769 & $3.32 \pm 0.11$ & $1.89 \pm 0.5$ \\
\hline $7-8$ & 52.61 & 1. & 743 & $2.36 \pm 0.15$ & - \\
\hline $8-9$ & 49.8 & & & $1 \pm 0.08$ & $3.44 \pm 0.09$ \\
\hline $9-10$ & 53.24 & & & $.14 \pm 1$ & $2.10 \pm$ \\
\hline $10-11$ & 53.87 & 1. & & $2.08 \pm 0$ & $0.86 \pm$ \\
\hline $11-12$ & 52.25 & $1.41 \mathrm{C}$ & .740 & $2.52+0.13$ & $1.76+0.45$ \\
\hline $12-13$ & 52.53 & 1.413 & 0.742 & $2.09 \pm 0.11$ & $2.30 \pm 0.73$ \\
\hline $13-14$ & 53.01 & 1.406 & 0.746 & $2.49 \pm 0.15$ & - \\
\hline $14-15$ & 53.70 & 1.398 & 0.751 & $2.36 \pm 0.04$ & $8.63 \pm 0.60$ \\
\hline $15-16$ & 55.73 & t & .766 & $2.56 \pm 0.18$ & - \\
\hline $16-17$ & 55.50 & 1 & & $47 \pm 0.05$ & $2.29 \pm 0.57$ \\
\hline $17-18$ & 54.79 & & & $6 \pm 0$ & $4.82 \pm 0$ \\
\hline 1$\}$ & & & & & $3 \pm 0.06$ \\
\hline-20 & 53.93 & 1. & .753 & $2.06 \pm 0.10$ & $8.68 \pm 0.53$ \\
\hline $20-22$ & 54.36 & 1.390 & 0.756 & $2.02 \pm 0$ & $6.65 \pm 0.62$ \\
\hline $22-24$ & 54.24 & 1.392 & 0.755 & $1.46 \pm 0.04$ & $19.0 \pm 0.5$ \\
\hline $24-26$ & 56.02 & 1.371 & 0.768 & $1.57 \pm 0.19$ & $14.1 \pm 0.7$ \\
\hline $26-28$ & 54.53 & 1.389 & 0.757 & $1.32 \pm 0.05$ & $35.1 \pm 0.3$ \\
\hline $28--30$ & 52.59 & 1.411 & 0.743 & $1.30 \pm 0.18$ & $13.2 \pm 0.2$ \\
\hline $30-33$ & 53.15 & 1.405 & 0.747 & $0.93 \pm 0.19$ & $11.2 \pm 0.4$ \\
\hline $33-36$ & 53.50 & 1.402 & .749 & $1.22 \pm 0.04$ & $4.29 \pm 0.64$ \\
\hline $36-39$ & 53.55 & 400 & 0.750 & $1.03 \pm 0.09$ & $3.85 \pm 0.64$ \\
\hline & & & & - & $7.14 \pm 0.09$ \\
\hline $42-45$ & 62.64 & & & - & $0.34 \pm 0.34$ \\
\hline $45-48$ & 80.80 & 1.134 & 0.916 & - & $3.73 \pm 0.78$ \\
\hline $48-51$ & 83.97 & 1.109 & & - & $3.82 \pm 0.80$ \\
\hline $51-54$ & 84.36 & 1.107 & 0.933 & - & - \\
\hline $54-57$ & 85.34 & 1.099 & 0.938 & - & $1.39 \pm 0.80$ \\
\hline $57-60$ & 85.73 & & & - & \\
\hline
\end{tabular}

Uncertainties are \pm 16 based on counting statistics

- Not detected due to poor chemical recovery. of the core was an unknown number of centimeters below the sediment-water interface (Stuiver 1967). It is also possible that his samples were contaminated by "dead carbon". If the longer term sedimentation rates measured by Stuiver is valid, it infers that recent land development has dramatically altered the physiography of an otherwise pristine terrain.

Deposition record of ${ }^{239.240} \mathrm{Pu}$ lends unequivocal support to the ${ }^{210} \mathrm{~Pb}$-based shorter-term sedimentation rate. Figure $2 \mathrm{c}$ shows that the downcore distribution of ${ }^{239,240} \mathrm{Pu}$ is characterized by a pronounced peak at the $26-28 \mathrm{~cm}$ interval which is undoubtedly related to the historical fallout maximum in 1963. Based on the ${ }^{210} \mathrm{~Pb}$-based sedimentation rate, the age of the $\mathrm{Pu}$ maximum layer corresponds to 1964-66. Allowing a time lag of 1-2 years for the transport of $\mathrm{Pu}$ from the stratosphere to the lake bottom, the ${ }^{210} \mathrm{~Pb}$ chronology agrees remarkably well with the stratigraphy of $\mathrm{Pu}$. Alternatively, considering possible crrors associated with the ${ }^{210} \mathrm{~Pb}$ chronology, there might be no time lag at all.

From the distribution of excess ${ }^{210} \mathrm{~Pb}$ and ${ }^{239.240} \mathrm{Pu}$ with respect to compaction corrected depth $\left(\mathrm{g} \mathrm{cm}^{-2}\right)$, inventories of these two nuclides can be calculated. The inventory of excess ${ }^{210} \mathrm{~Pb}$ is $\quad \mathrm{C} S / \lambda=3.70 \mathrm{dpm}$ $\mathrm{g}^{-1} \times 0.458 \mathrm{~g} \mathrm{~cm}^{-2} \mathrm{yr}^{-1} \div 0.0311 \mathrm{yr}^{-1}=54.5 \mathrm{dpm} \mathrm{cm}-2$. The ${ }^{210} \mathrm{~Pb}$ flux required to sustain this inventory is: $\mathrm{C}_{0} \mathrm{~S}=1.7 \mathrm{dpm} \mathrm{cm}^{2} \mathrm{yr}^{1}$. This value is very similar to atmospheric ${ }^{210} \mathrm{~Pb}$ fluxes observed elsewhere in the western Pacific: $2 \mathrm{dpm} \mathrm{cm}^{-2} \mathrm{yr}^{-1}$ in the western North Pacific area near Japan (Nozaki and Tsunogai 1973), $1.6 \mathrm{dpm} \mathrm{cm} \mathrm{cm}^{-2} \mathrm{yr}^{-1}$ in Okinawa (Tsunogai et al. 1985), and $1.8 \mathrm{dpm} \mathrm{cm}^{-2} \mathrm{yr}^{-1}$ near Hangzhou, China (DeMaster et al. 1985). These flux values are 3-10 times higher than ${ }^{210} \mathrm{~Pb}$ fallout observed in the north America continent (Appleby and Oldfield 1992). Since the flux of ${ }^{222} \mathrm{Rn}$ from the ocean surface is extremely low, fallout ${ }^{210} \mathrm{~Pb}$ in the western Pacific must be transported from the Asian continent by the Westerlies.

Because of variable input with time, the inventory of ${ }^{239.240} \mathrm{Pu}$ has to be calculated by adding up its activity downcore. The resulting value, $0.21 \mathrm{dpm} \mathrm{cm}{ }^{2}$ or $0.97 \mathrm{mCi} \mathrm{km}{ }^{-2}$, is in excellent agreement with the documented cumulative ${ }^{239,240} \mathrm{Pu}$ from global fallout $\left(0.96+0.07 \mathrm{mCi} \mathrm{km}^{-2}\right)$ at the $20-30 \mathrm{~N}$ latitudinal band (Hardy et al. 1973).

In conclusion this study presents the most reliable short-term $(<50$ yr) sediment chronology for Sun Moon Lake sediments and points to the suitability of the lake as a natural system for studying environmental changes.

Acknowledgements-The senior author wishes to thank the Oregon State University and the National Science Council of Taiwan, ROC for supporting his sabbatical research at the National Taiwan University where this work was conducted. We appreciate the invaluable expertise in sediment coring provided by Dr Kenneth Hsü.

\section{REFERENCES}

Appleby, P. G. and Oldfield, F. 1992. Applications of ${ }^{210} \mathrm{~Pb}$ to sedimentation studies. In Uranium-Series Disequilibrium-Applications to Earth, Marine, and Environmental Sciences (edited by $\mathbf{M}$. Ivanovich and R. S. Harmon), pp. 731 778. Clarendon Press, Oxford.

Bacon, M. P., Huh, C.-A.. Fleer, A. P. and Deuser, W. G. 1985. 
Seasonality in the flux of natural radionuclides and plutonium in the deep Sargasso Sea. Deep-Sea Res. 32, 273-286.

DeMaster, D. J., McKee, B. A., Nittrouer, C. A., Qian, J. and Cheng, G. 1985. Rates of sediment accumulation and particle reworking based on radiochemical measurements from continental shelf deposits in the East China Sea. Continental Shelf Research 4, 143-158.

Goldberg, E. D. 1963. Geochronology with ${ }^{210} \mathrm{~Pb}$ in radioactive dating. IAEA, Vienna, 121-131.

Hardy, E. P., Krey, P. W. and Volchok, H. L. 1973. Global inventory and distribution of fallout plutonium. Nature 241, 444-445.

Koide, M., Soutar, A. and Goldberg, E. D. 1972. Marine geochronology with ${ }^{210} \mathrm{~Pb}$. Earth Planet. Sci. Lett. 14, 442-446.

Krishnaswami, S., Lal, D., Martin, J. M. and Maybeck, M. 1971. Geochronology of lake sediments. Earth Sci. Lett. 11, 406-414.
Nozaki, Y. and Tsunogai, S. 1973. Lead-210 in the north Pacific and the transport of terrestrial material through the atmosphere. Earth Planet. Sci. Lett. 20, 88-92.

Sholkovitz, E. R. 1983. The geochemistry of plutonium in fresh and marine water environments. Earth-Science Reviews 19, 95-161.

Stuiver, M. 1967. Origin and extent of atmospheric ${ }^{14} \mathrm{C}$ variations during the past 10,000 years. In Radioactive Dating and Methods of Low-level Counting, pp. 27-40. International Atomic Energy Agency, Vienna, pp. 27-40.

Stuiver, M. 1970. Long-term C-14 variation. In Radiocarbon Variations and Absolute Chronology (edited by I. U. Olsson), pp. 197-213. Wiley Interscience Division, New York.

Tsunogai, S., Shinagawa, T. and Kurata, T. 1985. Deposition of anthropogenic sulfate and $\mathrm{Pb}-210$ on the western North Pacific area. Geochemical Journal 19, 77-90. 